\title{
Electrochemical Determination of Carboplatin in Serum Using a DNA- Modified Glassy Carbon Electrode
}

\author{
Ana Maria Oliveira Brett ${ }^{*+}$ Silvia H.P. Serrano, ${ }^{+}+++$Tice A. Macedo, ${ }^{++}$Dulce Raimundo, ${ }^{++}$M. Helena Marques ${ }^{++}$ \\ and Mauro A. La-Scalea ${ }^{+,++}$ \\ + Departamento de Química, Universidade de Coimbra, P-3000 Coimbra, Portugal \\ + Faculdade de Medicina, Universidade de Coimbra, P-3000 Coimbra, Portugal \\ +++ on leave from: Instituto de Química, Universidade de São Paulo, C.P. 26077, 05599-970 São Paulo, Brasil
}

Received: January 4, 1996

Final version: February 15, 1996

\begin{abstract}
An electrochemical method for the determination of the anticancer platinum drug carboplatin using a DNA-modified electrode was developed. This electrode was successfully used for the electrochemical determination of carboplatin in serum samples of patients with ovarian cancer undergoing treatment. The electrochemical results clearly demonstrated that, for low concentrations, carboplatin interacts preferentially with adenine rather than guanine groups in the DNA and they can contribute to clarifying the mechanisms of interaction of platinum anticancer drugs with DNA. The pharmacokinetics corresponding to the administration of the drug was followed electrochemically and the detection limit in serum samples was $5.7 \times 10^{6} \mathrm{M}$. Due to a similar mechanism of reaction with DNA other platinum anticancer drugs can be deternined by this method.
\end{abstract}

Keywords: Carboplatin, DNA, Anticancer drug, Modified electrode

\section{Introduction}

The objective of our work was to develop an electrochemical method for determination of anticancer platinum drugs, namely carboplatin. The anticancer activity of cis-dichloroamineplatinum(II) was discovered in 1969 [1], and successes with this compound were achieved in the treatment of testicular and ovarian cancers, both with cisplatin alone and in combination with other drugs. However, because of its toxic effects, more than 300 other platinum complexes were examined in the $1970 \mathrm{~s}$. Carboplatin, (cis-diammine-1,1-cyclobutanedicarboxylate) platinum(II) was selected for preclinical studies and it seems that less toxic effects may be due to higher solubility in water [2].

Several analytical methods have been described for the determination of cisplatin in biological matrices using HPLC with spectrometric detection [3-9] or LC with electrochemical detection systems [10-17]; the electrochemical behavior of cisplatin at dropping mercury [18], modified carbon paste and platinum [19] electrodes was also studied. However, there are fewer studies concerning the determination of carboplatin. Direct electrochemical determination is difficult because it does not have high electrochemical activity $[11,12,15]$. Only one anodic peak can be observed at very high potentials [20]. Because of this, derivatization procedures are carried out followed by analytical determination with spectrometric [6] or electrochemical [11] detection. In the latter case, carboplatin is converted to cisplatin which is then detected electrochemically.

This article describes analytical quantification of carboplatin in serum samples from women patients with ovarian cancer undergoing treatment with this drug, by using a DNA-modified glassy carbon electrode.

\section{Experimental}

Calf thymus DNA (sodium salt, type I), adenosine $5^{\prime}$ monophosphate and guanosine $5^{\prime}$-monophosphate were obtained from Sigma Chemical Co. and were used without further purification. Carboplatin was from David Bull
Laboratories $(150 \mathrm{mg} / 15 \mathrm{~mL})$. Preparation of single stranded DNA (ss DNA) was done by the following procedure. An accurately weighed sample of approximately $3 \mathrm{mg}$ of DNA was treated with $0.5 \mathrm{~mL}$ of pure perchloric acid. After dissolution, $0.5 \mathrm{~mL}$ of $9 \mathrm{M} \mathrm{NaOH}$ was then added to neutralize the solution followed by $9 \mathrm{~mL}$ of $\mathrm{pH} 4.6$ acetate buffer.

Adenosine $5 t$-monophosphate and guanosine 5 -monophosphate solutions of $1 \mathrm{mM}$ concentration were prepared by dissolution of appropriate weight in a solution containing $40 \mathrm{~mL}$ of $4.5 \mathrm{pH}$ acetate buffer with $5 \mathrm{~mL}$ of pure perchloric acid and $5 \mathrm{~mL}$ of $9 \mathrm{M} \mathrm{NaOH}$. Acetate buffer solutions of ionic strength 0.1 were used in all experiments at $\mathrm{pH} \mathrm{4.6}$, and were prepared using analytical grade reagents and purified water from a Millipore Milli-Q system.

Serum samples from patients undertaking a carboplatin (CBDCA) treatment, were provided by the Oncology Unit, Gynaecology Service, University Hospital of Coimbra, and were deproteinized by addition of 10\% trichloroacetic acid (1:1 $\mathrm{v} . / \mathrm{v}$.). After protein precipitation, the samples were centrifuged during $5 \mathrm{~min}$ at $2500 \mathrm{rpm}$. Carboplatin was determined at different times after the administration of the drug in the deproteinized serum samples. Serum blank samples were collected before the administration of the drug. The electrochemical cell contained $3.0 \mathrm{~mL}$ of $78 \mu \mathrm{g} / \mathrm{mL}$ ssDNA solution in acetate buffer electrolyte at $\mathrm{pH} 4.6$ to which was added $500 \mu \mathrm{L}$ of the deproteinized serum samples followed by standard additions of $20-50 \mu \mathrm{L}$ of $0.027 \mathrm{M}$ carboplatin in the experiments with ssDNA and $50 \mu \mathrm{L}$ of $0.5 \mathrm{mM}$ carboplatin in the experiments with adenosine. The same conditions were used in the electrochemical cell when $0.1 \mathrm{mM}$ of adenosine $5^{\prime}$-monophosphate or $0.1 \mathrm{mM}$ of guanosine $5^{\prime}$-monophosphate was used instead of ssDNA.

The working electrode was glassy carbon modified with adsorbed DNA, the counter electrode was a $\mathrm{Pt}$ wire, and the reference electrode was a SCE, all contained in a onecompartment cell. The DNA-modified electrode was prepared by covering a glassy carbon electrode (Tokai, GC20, area $0.07 \mathrm{~cm}^{2}$ ) with $3 \mathrm{mg}$ of DNA dissolved in $80 \mu \mathrm{L}$ of $\mathrm{pH} 4.5$ acetate buffer and leaving the electrode to dry. After drying, the electrode was immersed in acetate buffer solution and a constant 


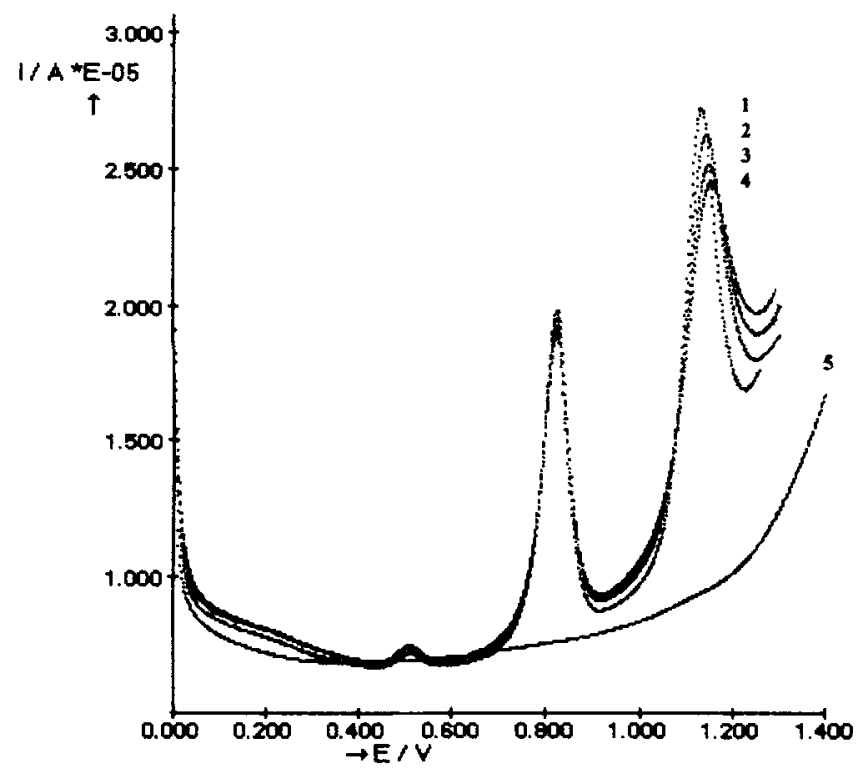

Fig. 1. Differential pulse voltammograms using a DNA-modified electrode of a solution of ssDNA, $78 \mu \mathrm{g} / \mathrm{mL}$ plus carboplatin concentrations of: 1) zero; 2) $84.4 \mu \mathrm{M}$; 3) $161 \mu \mathrm{M}$; 4) $236 \mu \mathrm{M}$ in pH 4.6 acetate buffer containing $0.5 \mathrm{~mL}$ of $5 \%$ trichloroacetic acid. 5) supporting electrolyte voltammogram. Pulse amplitude $50 \mathrm{mV}$, pulse width $50 \mathrm{~ms}$, scan rate $5 \mathrm{mV} \mathrm{s}^{-1}$.

potential of $+1.4 \mathrm{~V}$ applied during 5 minutes. Then it was transferred to a solution containing single stranded DNA. Differential pulse voltammograms were recorded, in order to evaluate the stabiblity of the DNA-modified glassy carbon, in the range 0 to $+1.4 \mathrm{~V}$.

Differential pulse voltammograms were recorded using a $\mu$ Autolab potentiostat/galvanostat running with GPES version 3 software, from Eco-Chemie, Utrecht, The Netherlands. The differential pulse voltammetry conditions were: pulse amplitude $50 \mathrm{mV}$, pulse width $70 \mathrm{~ms}$ and scan rate $5 \mathrm{mV} \mathrm{s}^{-1}$.

\section{Results and Discussion}

Platinum compounds bind covalently to DNA with cross links between two bases on opposite strands of the DNA helix and intrastrand cross links between two bases on the same DNA strand. The latter seems to be responsible for their antitumor

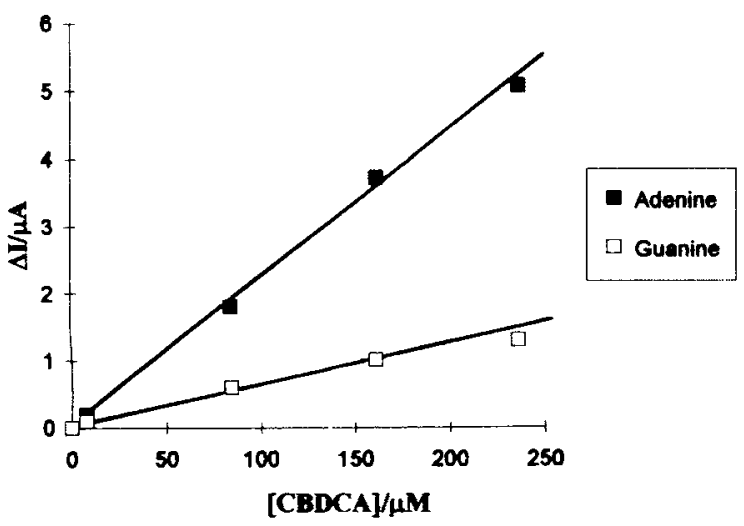

Fig. 2. Calibration plot for the decrease in the adenine $(\boldsymbol{D})$ and guanine (C) peak current corresponding to the addition of carboplatin to a $78 \mu \mathrm{g} /$ $\mathrm{mL}$ solution of ssDNA in $\mathrm{pH} 4.6$ acetate buffer containing $0.5 \mathrm{~mL}$ of $5 \%$ trichloroacetic acid.

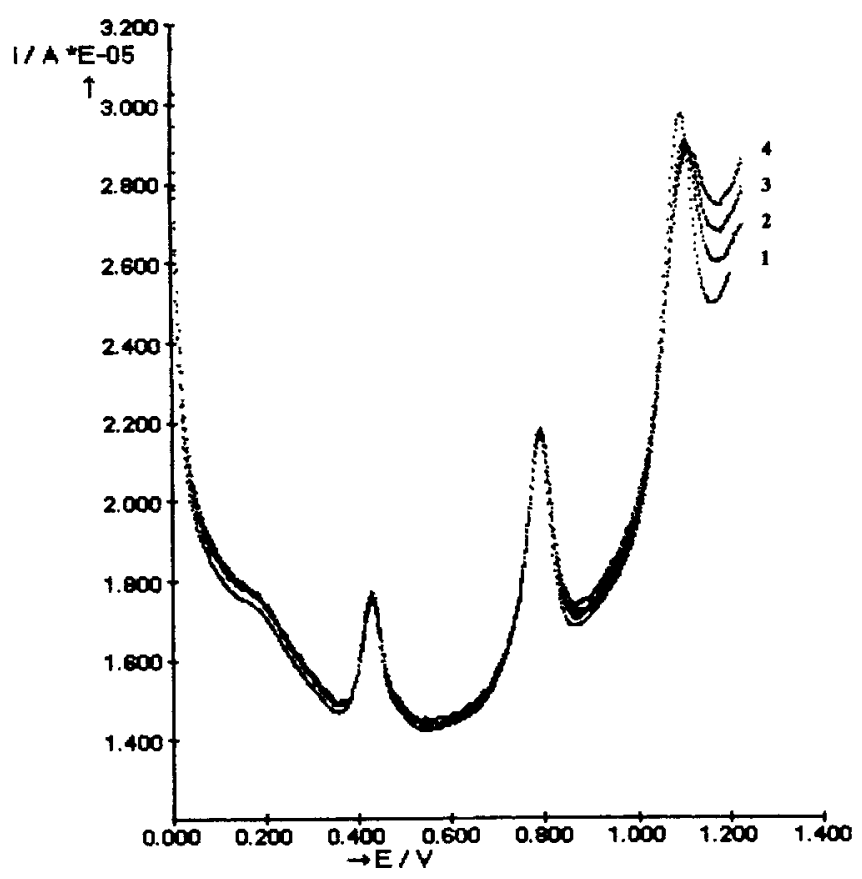

Fig. 3. Differential pulse voltammograms using a DNA-modified electrode of a solution of ssDNA, $78 \mu \mathrm{g} / \mathrm{mL}$ and $400 \mu \mathrm{L}$ of serum from a patient plus carboplatin concentrations of: 1) zero; 2) $0.39 \mathrm{mM}$; 3) $1.1 \mathrm{mM}$; 4) $1.5 \mathrm{mM}$; in $\mathrm{pH} 4.6$ acetate buffer containing $0.5 \mathrm{~mL}$ of $5 \%$ trichloroacetic acid. Pulse amplitude $50 \mathrm{mV}$, pulse width $50 \mathrm{~ms}$, scan rate $5 \mathrm{mVs}^{-1}$.

activity [21]. It was shown that these reactions occur preferentially with the N7 atoms of guanine [21-25].

Previous studies of single stranded DNA (ssDNA) electrooxidation showed two peaks that are identified as the oxidation peaks of guanine $(+0.87 \mathrm{~V})$ and adenine $(+1.12 \mathrm{~V})$ groups [26]. It is known that carboplatin binds covalently with DNA and so it seemed quite clear that it could be possible to develop an indirect analytical method to determine platinum compounds with antitumor activity by measuring this interaction. Thus a DNA-modified glassy carbon electrode was prepared and conditioned as described in the experimental section. After conditioning, stable oxidation currents were observed for the peaks corresponding to guanine and adenine when the electrode was placed in a ssDNA solution. Carboplatin was added to the solution containing ssDNA and, for the concentrations used,

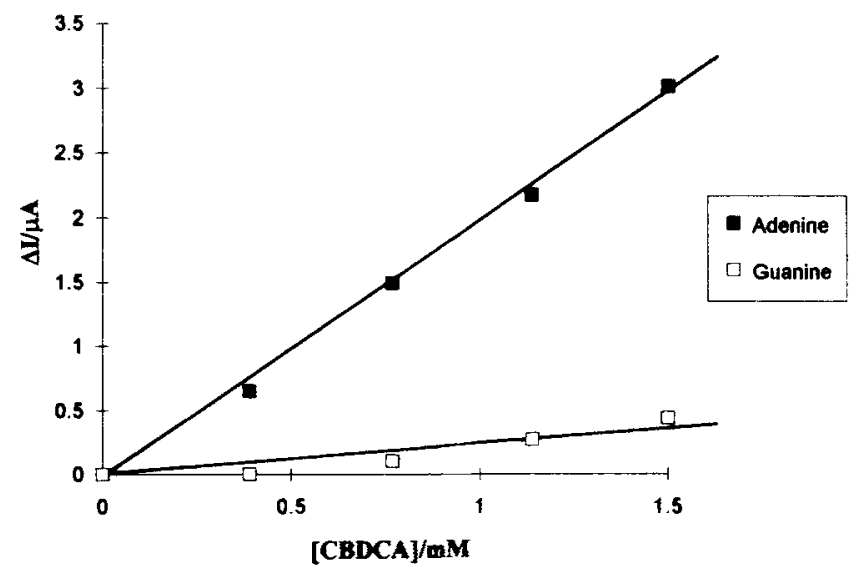

Fig. 4. Calibration plots for the decrease in the adenine ( $\square$ ) and guanine ( $\square$ ) peak current corresponding to the addition of carboplatin to a $78 \mu \mathrm{g} /$ $\mathrm{mL}$ solution of ssDNA and $400 \mu \mathrm{L}$ of serum from a patient in $\mathrm{pH} 4.6$ acetate buffer containing $0.5 \mathrm{~mL}$ of $5 \%$ trichloroacetic acid. 


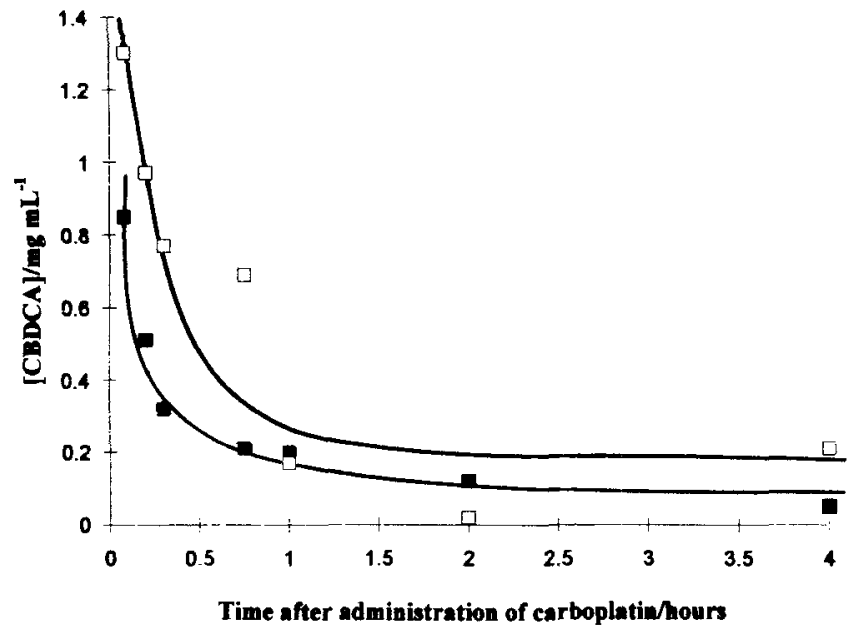

Fig. 5. Pharmacokinetic curves obtained using a DNA-modified electrode in a solution of ssDNA with serum, for two patients undertaking treatment with carboplatin.

the interaction with adenine was very clear from the results obtained for three consecutive additions of carboplatin as shown in the differential pulse voltammograms of Figure 1. The linear range of current decrease is $7.7 \times 10^{-6} \mathrm{M}$ to $2.4 \times 10^{3} \mathrm{M}$. There is a decrease in the oxidation current of adenine with increasing the concentration of the antineoplastic drug in solution while the guanine oxidation currents only decrease slightly. This is illustrated in Figure 2. The values on the $y$ axis are the variation in current corresponding to the difference between the current observed initially, before the addition of carboplatin, and after the addition of carboplatin $\left(\Delta I=I_{\text {initial }}\right.$ $\left.-I_{\text {carb }}\right)$. The response range for the determination of carboplatin in serum samples by the standard addition method using ssDNA solutions was in the range $6.5 \times 10^{-5} \mathrm{M}$ to $1.5 \times 10^{-3} \mathrm{M}$. No surface fouling by serum was observed.

Real samples were then employed to test the method. Serum samples were collected from two patients undertaking carboplatin treatment at different times after the administration of the drug. The experiments were performed in the conditions described in the experimental section. Differential pulse voltammograms, Figure 3, showed, besides the usual peaks for guanine and adenine, a new peak at a potential of $+0.43 \mathrm{~V}$ that

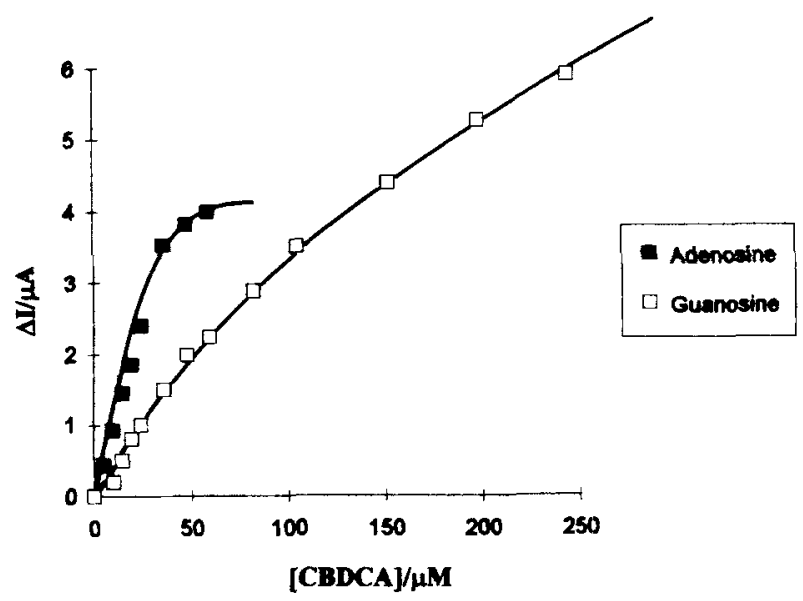

Fig. 6. Calibration plots for the decrease in the adenosine (D) or guanosine ( $\square$ ) peak current corresponding, respectively, to the addition of carboplatin to a solution of the nucleotides adenosine $5^{\prime}$-monophosphate or guanosine $5^{\prime}$-monophosphate in $\mathrm{pH} 4.6$ acetate buffer containing $0.5 \mathrm{~mL}$ of $5 \%$ trichloroacetic acid.

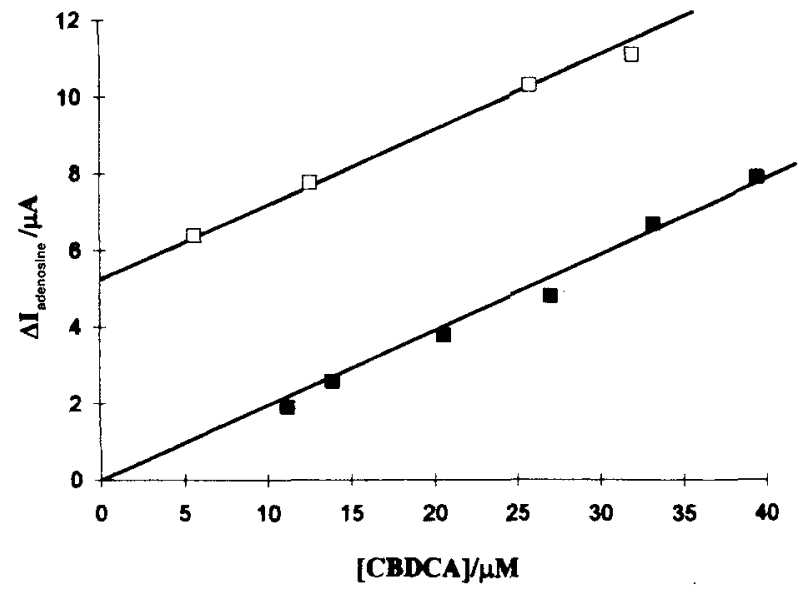

Fig. 7. Calibration plots for the decrease in the adenosine peak current corresponding to the standard addition of carboplatin to a $0.1 \mathrm{mM}$ solution of the nucleotide adenosine $5^{\prime}$-monophosphate and $500 \mu \mathrm{L}$ of serum from a patient in acetate buffer $\mathrm{pH} 4.6$ containing $0.5 \mathrm{~mL}$ of $5 \%$ trichloroacetic acid: serum of the patient ( $\square$ ) before and ( $\square$ ) $8 \mathrm{~h}$ after administration of carboplatin.

corresponds to uric acid existing in serum and coming from normal human metabolism. The calibration plot is presented in Figure 4 and, again, the interaction with adenine is much higher than with guanine. The evaluation of the pharmacokinetics of the drug during treatment is in Figure 5, for two patients, and an exponential type decay was observed as expected. It is interesting to note that the levels of carboplatin in the serum vary slightly between patients which is not surprising and is due to different stages of the disease and individual reaction to the treatment.

Our results, obtained using electrochemical methods, clearly indicate preferential interaction of carboplatin with the adenine groups in the ssDNA solution, during the time scale of the voltammetric experiments, i.e., less than $10 \mathrm{~min}$, and almost no reaction with guanine groups. Results described by previous workers using NMR and longer reaction times [21-24], showed a preferential interaction of carboplatin with the guanine groups. In order to clarify this apparent contradiction we studied the interaction of carboplatin with the nucleotides adenosine 5 -monophosphate and guanosine 5 -monophosphate separately. The concentrations of the nucleotides were $0.1 \mathrm{mM}$ signifying a small molar carboplatin/nucleotide ratio.

From the results obtained, Figure 6, the conclusion is that for low concentrations of carboplatin $\left(\sim 10^{-6} \mathrm{M}\right)$ there is a

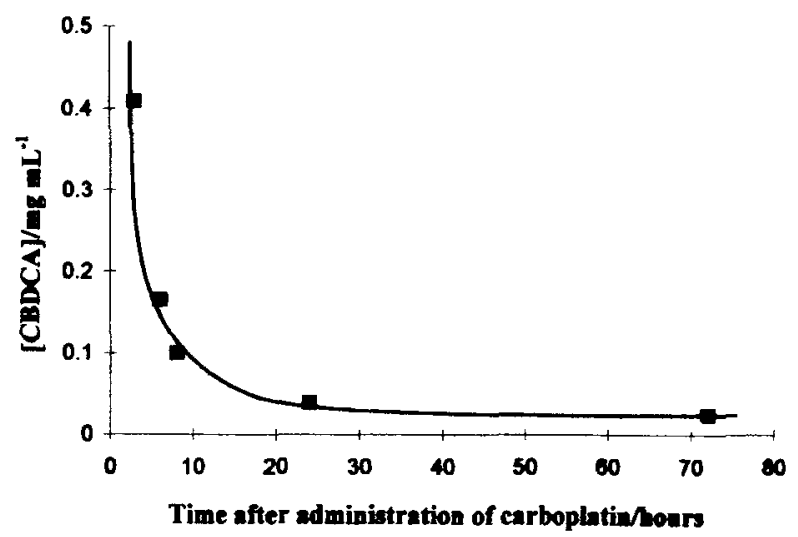

Fig. 8. Pharmacokinetic curve obtained using a DNA-modified electrode in a solution of the nucleotide adenosine $5^{\prime}$-monophosphate with serum, for a patient undertaking treatment with carboplatin. 
preferential interaction with adenosine which is proportional to concentration and that saturates at higher concentrations. The shape of this plot suggests the formation of a complex between carboplatin and adenosine. The guanosine-carboplatin interaction for low concentrations of carboplatin is much less but increases steadily even at higher concentrations where the interaction with adenosine is not increasing measurably. Considering that previous researchers [21-24], mainly because of the specifications of the methods they were using, always used concentrations of carboplatin three orders of magnitude higher, $10^{-2}-10^{-3} \mathrm{M}$, there is, effectively, no discrepancy with our results. It also shows that the electrochemical methods can throw light on this type of mechanism as they enable much lower concentrations of the analytes to be used. In fact, the linear response range for the determination of carboplatin by the standard addition method using the nucleotide adenosine $5^{\prime}-$ monophosphate solution in aqueous solution or in serum samples is in the range of $5.7 \times 10^{-6} \mathrm{M}$ to $4.0 \times 10^{-5} \mathrm{M}$.

Instead of using the nucleotides adenosine $5^{\prime}$-monophosphate or guanosine 5 -monophosphate we also did the same experiments for carboplatin with the free bases guanine and adenine. However, no linear relationship between the decrease in the oxidation currents with increasing concentration of carboplatin was observed meaning that other groups are involved in the interaction reaction and contribute to the stabilization of the products.

After these experiments it seemed that in order to determine carboplatin in serum samples of patients with cancer disease it was not necessary to quantify the interaction with ss DNA as we could easily use the nucleotide adenosine $5^{\prime}$-monophosphate. This is very important as it is much less expensive than ssDNA, and simplifies HPLC separation used in conjunction with electrochemical detection. The stability and reproducibility of the adenine peak without the drug using the DNA-modified glassy carbon electrode was excellent.

The DNA-modified electrode was used to determine the concentration of carboplatin in serum samples of a third patient following administration of carboplatin using the standard addition method and following interaction with the nucleotide adenosine $5^{\prime}$-monophosphate. To determine the linear response range in the biological matrix, a calibration plot done using the nucleotide adenosine $5^{\prime}$-monophosphate solution plus serum sample that was collected before the administration of the drug, Figure 7, and standard addition was used to determine the concentration of carboplatin containing serums collected at different times after administration of the drug.

The pharmacokinetic curve is presented in Figure 8 and shows that in a $72 \mathrm{~h}$ period the concentration of the drug decreased exponentially with time as expected. However, for more than $72 \mathrm{~h}$ after administration of the drug the concentration of carboplatin in the serum samples is lower then the detection limit of $5.7 \times 10^{-6} \mathrm{M}$ and could not be determined.

\section{Conclusions}

The DNA-modified electrode can be used for electrochemical determination in serum samples of patients with ovarian cancer undergoing treatment with carboplatin. The pharmacokinetics corresponding to the administration of the drug can be followed by electrochemical methods and the detection limit in serum samples is $5.7 \times 10^{-6} \mathrm{M}$. Other platinum anticancer drugs can be determined by this method but this does not create problems of selectivity since they will not be given simultaneously to the patient and the electrochemical method can always be used in a flow system in conjunction with HLPC separation. Besides the electroanalytical merits of this method it is clearly demonstrated that, for low concentrations, carboplatin interacts preferentially with adenine rather than guanine groups in the DNA and that electrochemical methods can contribute to clarifying the mechanisms of interaction of platinum anti-cancer drugs with DNA.

\section{Acknowledgements}

We thank "Fundação de Amparo à Pesquisa do Estado de São Paulo (FAPESP), Brasil" for a post-doctoral fellowship to S.H.P. Serrano, and CNPq for a fellowship to M.A. La-Scalea.

\section{References}

[1] B. Rosenberg, L. Van Camp, T. Krigas, Nature, 1965, 205, 698.

[2] K.R. Harrap, Cancer Trear. Rev. 1985, 12 (supplement A), 21

[3] S.J. Bannister, L.A Sternson, A.J Repta, J. Chromatogr. 1979, 173, 333

[4] C.M. Riley, L.A. Sternson, A.J. Repta, J. Chromatogr. 1981, 217, 405.

[5] O.H. Drummer, A. Prodfoot, L. Howes, W.J. Louis, Clin. Chim. Acta $1984,136,65$

[6] K.C. Marsh, L.A Sternson, A.J. Repta, Anal. Chem. 1984, 56, 491.

[7] W.R. L. Cairns, L. Ebdon and S.J. Hill, Anal. Proc. 1994, 31, 295.

[8] C.M. Riley, L.A. Sternson, A.J. Repta, R.W. Sicgler, J. Chromatogr. Biomed. Appl. 1982, 229, 373.

[9] W.A.J. De Waal, F.J.M.J. Maessen, J.C. Kraak, J. Chromatogr. 1987, 407,253

[10] W. N. Richmond, R.P. Baldwin, Anal. Chim. Acta 1983, 154, 133.

[11] I.S. Krull, X-D. Ding, S. Braverman, C. Selavka, F. Hochberg, L.A. Sternson, J. Chromatogr. Sci. 1983, 21, 166.

[12] S.J. Bannister, L.A. Sternson, A.J. Repta, J. Chromatogr. 1983, 273, 301.

[13] P.J. Parsons, A.F. LeRoy, J. Chromatogr. 1986, $378,395$.

[14] G.M Smith, D.R. Atherton, Anal. Chem. 1986, 58, 1956.

[15] P.J. Parsons, P.F. Morrison, A.F. LeRoy, J. Chromatogr. 1987, 385, 323.

[16] P. O'Dea, P. Shearan, S. Dunne, M.R. Smyth, Analyst 1988, 113, 1791

[17] K. Digua, J.-M. Kauffmann, G. Ghanem, G.J. Patriarche, J. Liquid Chromatogr. 1992, 15, 3295.

[18] V. Brabec, V. Vetterl, V. Kleinwächter, J. Reedijk, Bioclectrochem Bioenerg. 1989, 21, 199.

[19] F. Mebsout, J.-M. Kauffmann, G.J. Patriarche, J. Pharm. Biomed. Anal. $1988,6(5), 441$.

[20] F. Mebsout, J.-M. Kauffmann, G.J. Patriarche, J. Pharm. Biomed. Anal. 1987, 5 (3), 223.

[21] P.J. Stone, A.D. Kelman, F.M. Sinex, Nature (London) 1974, 25l, 736

[22] S. Mansy, G.Y.H. Chu, R.E. Duncan, R.S. Tobias, J. Am. Chem. Soc 1978, $100,607$.

[23] S.E. Sherman, J.S Lippard, Chem.Rev. 1987, 87, 1153.

[24] W.M. Scovell, T. O'Connor, J. Am. Chem. Sor. 1977, 99, 120.

[25] D.P. Bancroft, C.A. Lepre, S.J. Lippard, J. Am. Chem. Soc. 1990, 112 , 6860.

[26] C.M.A. Brett, A.M. Oliveira Brett, S.H.P. Serrano, J. Electroanal. Chem. 1994, 366, 225. 